\title{
ETHICS AND STRATEGY IN DECISION-BASED DESIGN FRAMEWORKS: PROBLEMS AND SOLUTIONS
}

\author{
Hulse, Daniel; Hoyle, Christopher; Tumer, Irem \\ Department of M.I.M.E., Oregon State University
}

\begin{abstract}
Engineering Design decisions impact customers, the environment and society at large in ways that have profound ethical and strategic implications for designers. Previous research in decision-based design has proposed the decisions should be made on the basis of maximizing the expected utility of the design to the designer. This paper discusses ethical and strategic challenges for these frameworks across five levels: the axioms that underlie utility, the definition of utility, the consideration of multiple stakeholders, the modeling scope, and resulting design framework implementation. Based on these problems, solutions are suggested to account for each in the development of improved, ethicallyinformed frameworks. Challenges presented here do not prohibit the prudent use of decision-based design frameworks per se, but instead point to cases that must addressed in practice while providing grounds for further research towards the development of decision-based design frameworks that are ethical by design.
\end{abstract}

Keywords: Decision making, Ethics, Design theory

\section{Contact:}

Hulse, Daniel Edison

Oregon State University

Department of Mechanical, Industrial, and Manufacturing Engineering

United States of America

hulsed@oregonstate.edu 


\section{INTRODUCTION}

Engineering design impacts economic development and progress, public safety, global conflicts, and environmental sustainability. Often, design decisions have high stakes, up to that of lives lost. For example, the decision of safety risk for various events deemed "acceptable" presents a clear, profound, and difficult trade-off between the economic and practical usefulness of a system and the potential for disaster, but nevertheless a decision must be made. As Goebel et al. (2019) note in the field of prognostics and health management, the increasing automation of previously human tasks is pushing the purview of ethical decision-making from management to engineering. Considering the profound impact of engineering decisions and the increasing bearing of ethics on engineering decision-making, it is important that prescribed decision-making processes are not only based on sound axioms and evidence, but consistent with fundamental human values.

Decision-based design (DBD) has been proposed in the design literature as a normative approach to engineering decision-making (Hazelrigg, 1998). Such approaches, as presented by Lewis et al. (2006), as well as the value-driven design approaches of Collopy and Hollingsworth (2011) are constructed on the principle of maximizing the expected utility of the design to the producer, following the axioms of Von Neumann and Morgenstern, where utility is most often a function of cost. "Normative" as it is used when referring to decision-making frameworks (and throughout this paper), refers to the way decisions ought to be made. This definition takes lineage from the use of the term in economics (Simon, 1959), where normative economics (the prescription of policy measures to meet desired outcomes) is often contrasted with positive economics (the science of objectively characterizing the behavior of the economy (Friedman, 1953)). However, the claim that decision-based design is normative is quite extraordinary, because the concept of normativity is defined not just by the pursuit of self-interest, but by ethics, values, and the interests of society (Amy, 1984).

While some critiques have been presented to decision-based design, it has largely been upheld as a generally valid theory in the design community for good reason-not only are the underlying axioms of decision-based design generally defensible (Thurston, 2001), the approaches present real improvements over previously-adopted decision-making approaches in terms of logical consistency (Hazelrigg, 1996) and validity to design (Olewnik and Lewis, 2008). Previous critiques, however, have not been made from the perspective of design ethics. As decision-based design approaches become recommended as best practice for design, it becomes increasingly important to consider and address the ethical issues apparent in existing approaches so that they can be further developed into generally-applicable ethical frameworks. While some (mostly parenthetical) comments have been given in the context of decisionbased design approaches to formulate such decision processes based on organizational and ethical values (see: (Lee and Paredis, 2014), (Soban et al., 2012) and (Wood, 2004)), the concept has not been explored in depth and very little guidance has been given as a result.

\subsection{Contribution and approach}

The contribution of this work is a constructive critique of decision-based design frameworks from the perspective of ethics which will spur the development of decision-based design theories that are not only axiomatically valid, but consistent with the engineer's ethical role in society. In service of this critique, potential ethical problems are presented across the epistemic scope of decision-based design, from the axioms and definitions of utility (i.e. the theoretical foundation) to the implementation of such frameworks (i.e. the framework as it is used in practice), as illustrated in Figure 1. As the purpose of this paper is to provide a constructive critique, for each problem identified, some attempts at a solution are provided which may be incorporated and validated in future approaches.

The approach taken to form this critique is as follows: Potential issues were identified using an affinity diagram-specific potential problems were first brainstormed and then organized around general assumptions required for decision-based design to be normative. Then, literature was reviewed in engineering design and fields adjacent to decision-based design frameworks, including economics, management/operations research, marketing, and sustainability to find support for any of these themes. Then, for each of these issues found in literature, potential solutions for these issues were brainstormed and reported in this review after a check to see if any similar solutions exist in the literature of the reviewed fields. 


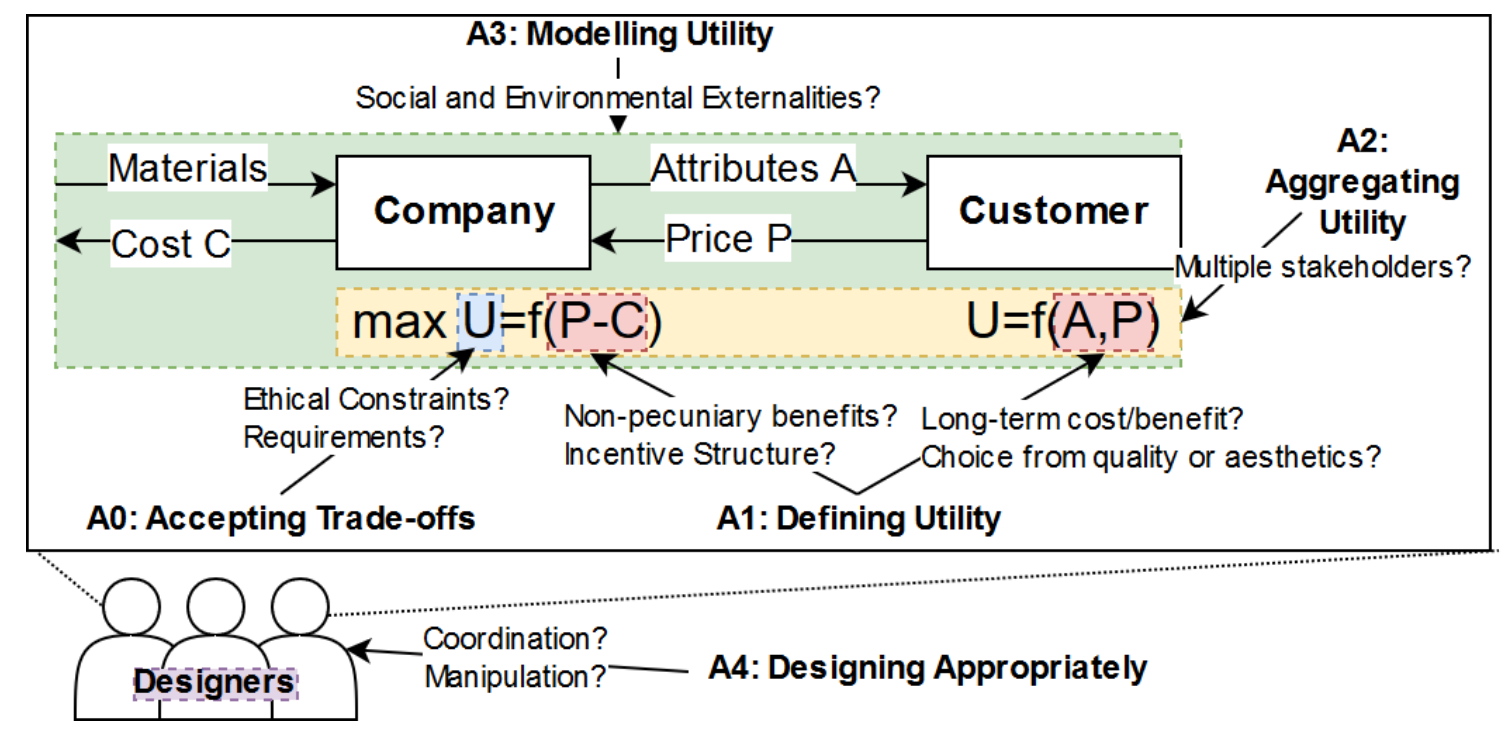

Figure 1. The validity of decision-based design frameworks relies on key assumptions about trade-offs, utility form, the scope of consideration, and designer behavior.

\section{PROBLemS AND SOLUTIONS}

To accept decision-based design as a normative (rather than merely expedient) approach to engineering decision-making, one must first first accept a series of assumptions, as shown in Figure 1 for a typical framework. In this framework, the company exchanges a product with attributes $A$ to a customer, which chooses between several products with different attributes $A$ and pays a certain price $P$ in exchange for their chosen product. Based on the total demand of a series of customers paying prices for different products, the company then realizes revenue from those transactions, as well as costs $C$ associated with producing those attributes, which in combination give a net profit for the set of attributes of the product. The utility $U$ is then a function of this profit as well as the uncertainty the designer has in achieving it according to their risk preferences.

Five main assumptions are required for accepting the this approach as ethical, which will be expanded on in the next subsections. The foundational assumption (A0 in Figure 1) is that trade-offs may be made ethically in the design as a utility value and that there are no "must have" constraints that the designer simply cannot ethically violate, and is discussed in Section 2.1. The first assumption (A1) is then that the attributes used to define this utility number completely characterize the actual normative preferability of a design, and is discussed in Section 2.2. The second assumption (A2) is that only the company's utility is worth considering to achieve an ethical design, and is discussed in Section 2.3. The third assumption (A3) is that it is appropriate to only consider and model the transaction between the company and customer, and not interacting social and environmental effects, and is discussed in Section 2.4. The final assumption (A4) is that designers, using this framework, will design appropriately without manipulating decisions to unethical ends, and is discussed in Section 2.5.

\subsection{Assumption 0: The appropriateness of accepting trade-offs}

In decision-based design frameworks, using expected utility as the sole design metric allows designers to make trade-offs between competing and uncertain objectives in the design (Hazelrigg, 1998) (Collopy and Hollingsworth, 2011). However, for the use of this metric to be truly normative, the metric must negotiate these trade-offs in a way that is not only expedient, but ethical as well. In many design cases, however, ethical trade-offs simply cannot be made due to legal requirement. Additionally, some ethical frameworks do not allow the consideration of tradeoffs, because they do not encode values as objectives, but as rules that must be followed, as outlined in Table 1. Furthermore, there are many design cases in which, because of legal and contractual considerations between the designer and the buyer, the designer cannot make trade-offs that would violate that agreement. The general solution to these problems is to incorporate these considerations as constraints and only explore design options the designer has a right to explore, however these problems cannot be fixed easily if one does not accept utilitarianism for the purpose of design. 
Table 1. Examining the appropriateness of accepting trade-offs in design.

\begin{tabular}{|l|l|l|}
\hline Issue & Basis in Literature & Potential Solution \\
\hline Ethical Frameworks & $\begin{array}{l}\text { Multi-criteria decision analysis is incom- } \\
\text { patible with non-utilitarian ethical frame- } \\
\text { works (Wenstøp, 2005). }\end{array}$ & $\begin{array}{l}\text { Accept utilitarianism for the } \\
\text { purpose of design. Incorpo- } \\
\text { rateontological obligations } \\
\text { as constraints, despite prob- } \\
\text { lems identified by (Le Men- } \\
\text { estrel, 2005). }\end{array}$ \\
\hline $\begin{array}{l}\text { Legal } \\
\text { Considerations }\end{array}$ & $\begin{array}{l}\text { Engineering design is often constrained } \\
\text { by contracts that dictate requirements } \\
\text { (Schwartz, 2010). }\end{array}$ & $\begin{array}{l}\text { Revise contracts to allow } \\
\text { for value optimization. } \\
\text { Incorporate requirements as } \\
\text { constraints. }\end{array}$ \\
\hline & $\begin{array}{l}\text { Engineering design is constrained by reg- } \\
\text { ulation that reflects the public's will (see: } \\
\text { (Newman, 2004) for an example). }\end{array}$ & $\begin{array}{l}\text { Incorporate regulation as a } \\
\text { constraint. }\end{array}$ \\
\hline
\end{tabular}

\subsection{Assumption 1: defining utility}

Key to maximizing the expected utility of a design is first modelling the utility as a function of desirable attributes or objectives. In typical approaches, utility is a function of the benefit of the product to the producer (Hazelrigg, 1998), which can be determined by modeling the cost of production and the revenue generated by the customer's probability of choice resulting from their hidden utility for the product (Wassenaar and Chen, 2003). However, to accept that this process is good for the customer, one must first accept that the choice the customer makes is directly correlated to their welfare. Recent developments in behavioral economics and marketing literature have challenged this notion, as shown in Table 2. Additionally, the direct profit of a design is not always the sole metric that a design organization must consider, since incentive structures vary for different organizations and there may be good reasons to invest in non-choice determining variables for long-run returns. The prospective approach to account for these issues is to additionally consider the costs and benefits of the product to customers outside of the benefit the producer experiences from their direct choice. Considering the consumer's appreciation of quality over time (Pahl and Beitz, 2007, Sec. 5.3), this consideration may even pay off in the long run as the customer gains an affinity for the product and brand. Finally, an organization's utility function may need to be extended from profit to align with the organizational goals and incentive structure if it does not operate purely as a profit-maximizing company. However, much further work will need to be done in this area to enable this, since current frameworks rely heavily on direct profit from an immediate transaction.

\subsection{Assumption 2: aggregating utility}

Decision-based design frameworks aim to maximize the utility of the design to the producer Hazelrigg (1998) as a means of avoiding perceived social choice problems (Hazelrigg, 1996). However, framing design as merely an optimization of producer utility presents a number of moral hazards in the design process, as shown in Table 3. If the incentives of the design organization represented by the utility metric are not properly aligned with stakeholder interests (that is-if it will not receive meaningful punishment or reward as a result of its design work), merely considering the organization's utility could cause it to design features that are of undesirable quality. While market mechanisms often allow for producer and stakeholder interests to be aligned, design does not always take place in a market scenario, and the market does not always function well. For a true, general claim of normativity, therefore, some consideration of the utility created by the design to all stakeholders must take place, even if doing so results in challenges due to aggregation. Creating design frameworks to approach these problems will likely require further adaptation of new innovations in social choice literature as well adapting ethical frameworks about justice and fairness. 
Table 2. Examining the appropriateness of considering profit andlor choice as a the sole metric of utility.

\begin{tabular}{|l|l|l|}
\hline Issue & Basis in Literature & Potential Solution \\
\hline Utility as Choice & $\begin{array}{l}\text { Consumers are not rational agents whose } \\
\text { preferences reflect their actual well- } \\
\text { being. Consumers can choose products } \\
\text { that actually harm them in the long-run } \\
\text { (Thaler, 1980) (Gruber, J. and Köszegi, } \\
\text { B., 2001). }\end{array}$ & $\begin{array}{l}\text { Consider the explicit lifecycle } \\
\text { cost/benefit of the product to } \\
\text { the customer in overall assess- } \\
\text { ment of utility. Examine incon- } \\
\text { sistencies between the cus- } \\
\text { tomer's stated and revealed } \\
\text { preferences to determine if the } \\
\text { choice is rational or compul- } \\
\text { sive (Noor, J., 2011). }\end{array}$ \\
\hline \multirow{7}{*}{$\begin{array}{l}\text { Considered } \\
\text { Attributes }\end{array}$} & $\begin{array}{l}\text { Consumer choice is subject to manipula- } \\
\text { tion based on the framing of the product } \\
\text { (Tversky and Kahneman, 1981). }\end{array}$ & $\begin{array}{l}\text { "Nudge" consumers to ethical } \\
\text { choices that are in their own } \\
\text { interest (Thaler and Sunstein, } \\
\text { 2008). }\end{array}$ \\
\hline $\begin{array}{l}\text { Customer judgements are aesthetic and } \\
\text { nased on signifiers, rather than true engi- } \\
\text { neering variables (Nelissen and Meijers, } \\
\text { 2011) (Dawar and Parker, 1994). }\end{array}$ & $\begin{array}{l}\text { Ensure the design delivers on } \\
\text { the value proposition implied } \\
\text { by the signals given to the cus- } \\
\text { tomer. }\end{array}$ \\
\hline $\begin{array}{l}\text { Organizations do not always maxi- } \\
\text { mize profit, and may have varying } \\
\text { non-pecuniary benefits (Furubotn, 1985) } \\
\text { (Feinberg, 1975) and incentive structures } \\
\text { (James, 1983) depending on the type. }\end{array}$ & $\begin{array}{l}\text { Define utility differently } \\
\text { from profit, when required to } \\
\text { express organizational goals } \\
\text { and values. }\end{array}$ \\
\hline $\begin{array}{l}\text { Customer choices change over long } \\
\text { timescales based on customer's assess- } \\
\text { ment of brand quality (Dawar and Parker, } \\
\text { 1994) (Doyle, 1989). }\end{array}$ & $\begin{array}{l}\text { Consider quality as a long- } \\
\text { term investment and model } \\
\text { its long-term effects on choice } \\
\text { (Sheth and Sisodia, 2002) and } \\
\text { customer well-being. }\end{array}$ \\
\hline
\end{tabular}

Table 3. Examining the appropriateness of considering the producer to be the sole stakeholder in design.

\begin{tabular}{|l|l|l|}
\hline Issue & Basis in Literature & Potential Solution \\
\hline Stakeholder Scope & $\begin{array}{l}\text { Moral hazards exist when considering } \\
\text { the designer or design organization to be } \\
\text { the sole stakeholder because the designer } \\
\text { (see: (Toh et al., 2015)) or design orga- } \\
\text { nization (see: (Bresnahan, 1999) (Anton } \\
\text { and Yao, 1995)) will be prone to manip- } \\
\text { ulate the competitive environment for its } \\
\text { own benefit at the expense of other stake- } \\
\text { holders. }\end{array}$ & $\begin{array}{l}\text { latity of multiple stakehold- } \\
\text { ers in design (such as (Zhuang } \\
\text { from social choice innovations, } \\
\text { such as the utilitarian voting } \\
\text { (Hillinger, 2005) and major- } \\
\text { ity judgment (Balinsky and } \\
\text { Laraki, 2011) which are not } \\
\text { subject to Arrow's Impossibil- } \\
\text { ity Theorem. }\end{array}$ \\
\hline $\begin{array}{l}\text { Allocation } \\
\text { Equity }\end{array}$ & $\begin{array}{l}\text { and } \\
\text { the design process, making it difficult to } \\
\text { prioritize one stakeholder over another, } \\
\text { such as considering the safety of pas- } \\
\text { sengers versus pedestrians (Awad et al., } \\
\text { 2018). }\end{array}$ & $\begin{array}{l}\text { Draw from philosophical the- } \\
\text { ories of justice, such as the } \\
\text { "veil of ignorance" principle } \\
\text { proposed by Rawls (1971) to } \\
\text { trade off between competing } \\
\text { interests. }\end{array}$ \\
\hline
\end{tabular}

\subsection{Assumption 3: modeling utility}

Modelling assumptions about the environment can play a significant role in the ethical consideration of decision-based design frameworks. From the point of view of sustainable design, this is because of 
the effects of the engineered system in three interacting environments: the environmental, social, and economic system (Rosen and Kishawy, 2012) (Howarth and Hadfield, 2006), as illustrated in Figure 2. As discussed in Table 4 from this perspective, a broader consideration of utility (one based on overall well-being), would require the larger system to be considered in the design of the product to account for externalities-effects of the product not accounted for in the the market price-which realize themselves in the environment and social system. Additionally, considering the utility from the perspective of fairness requires a consideration of the proportion of utility gained by each stakeholder as well as the power dynamics between them. This becomes important, for example, in a monopoly market situation between customers and producers in which the producer has the power to set both price and product attributes without the customer having a meaningful choice.

The general approach identified here to solve these problems is to change the incentives to directly represent the overall cost or benefit of a given design, such as by quantifying and incorporating the cost or benefit of the external effect or by designing as if there was competition when there is none in reality. However, because of complexities in these environments, without a good model it may be difficult to achieve desired effects, and there may be unintended consequences, as identified by Walsh et al. (2019). Approaching the problem of environmental complexity may, as a result, require the use of systems thinking or systems modelling approaches, as proposed in early decision-based design frameworks to help comprehend complexity in the engineering process (Mistree, 1990) .

Table 4. Examining issues with developing models of utility based on direct cost.

\begin{tabular}{|l|l|l|}
\hline Issue & Basis in Literature & Potential Solution \\
\hline Market & $\begin{array}{l}\text { Examples exist (Gilbert and Newbery, } \\
\text { 1982) (Leitzel, 1992) in which the engi- } \\
\text { neering market environment is not com- } \\
\text { petitive and as a result does not give } \\
\text { customers meaningful choices, making } \\
\text { profit-maximization economically ineff- } \\
\text { cient (Taylor et al., 2014, Chapter 9-10). }\end{array}$ & $\begin{array}{l}\text { Make decisions as if the market sit- } \\
\text { uation was competitive by present- } \\
\text { customers. }\end{array}$ \\
\hline $\begin{array}{l}\text { Environmental } \\
\text { Externalities }\end{array}$ & $\begin{array}{l}\text { Environmental effects of products, such } \\
\text { as pollution and resource use often do not } \\
\text { factor into the direct cost of the product, } \\
\text { but nonetheless create real harms (Taylor } \\
\text { et al., 2014, Chapter 12). }\end{array}$ & $\begin{array}{l}\text { Make decisions based on broad eco- } \\
\text { nomic and environmental effects } \\
\text { over the lifecycle of the product } \\
\text { by quantifying the costs of envi- } \\
\text { ronmental effects (see: (Kobayashi, } \\
\text { 2005) and (Bradley et al., 2018)). }\end{array}$ \\
\hline Social & $\begin{array}{l}\text { The environmental effects of products } \\
\text { are often complex and counter-intuitive } \\
\text { when viewed solely from the perspective } \\
\text { of efficiency (Alcott, 2005) (Meadows, } \\
\text { 1999). }\end{array}$ & $\begin{array}{l}\text { Model environmental effects using } \\
\text { appropriate system modelling } \\
\text { approaches, such as system dynam- } \\
\text { ics approaches (as in (Meadows } \\
\text { et al., 1972)) or probabilistic graph } \\
\text { modelling Telenko (2012). }\end{array}$ \\
\hline $\begin{array}{l}\text { Externalities } \\
\text { effects, such to power dynamics between } \\
\text { warring nations (Killmister, 2008) and } \\
\text { the rise of new political movements } \\
\text { (Shirky, 2011). }\end{array}$ & $\begin{array}{l}\text { Use systems thinking approaches } \\
\text { (as in (Watz and Hallstedt, 2018)) } \\
\text { or strategic game models to identify } \\
\text { the external social effects to various } \\
\text { actors. }\end{array}$ \\
\hline
\end{tabular}

\subsection{Assumption 4: designing appropriately}

The final problem for decision-based design is the implementation and execution of the framework in practice. Even if the theory and inputs of a design framework are correct, there is still room for error in the way people use the frameworks in practice. Some literature has explored these issues using computational models (see: (Collopy and Poleacovschi, 2012) (Bhatia et al., 2016)) because they are of direct relevance to the actual effectiveness of decision-based design frameworks in practice. However, present issues are shown in Table 5. To summarize, effective design is contingent on coordinating designers 


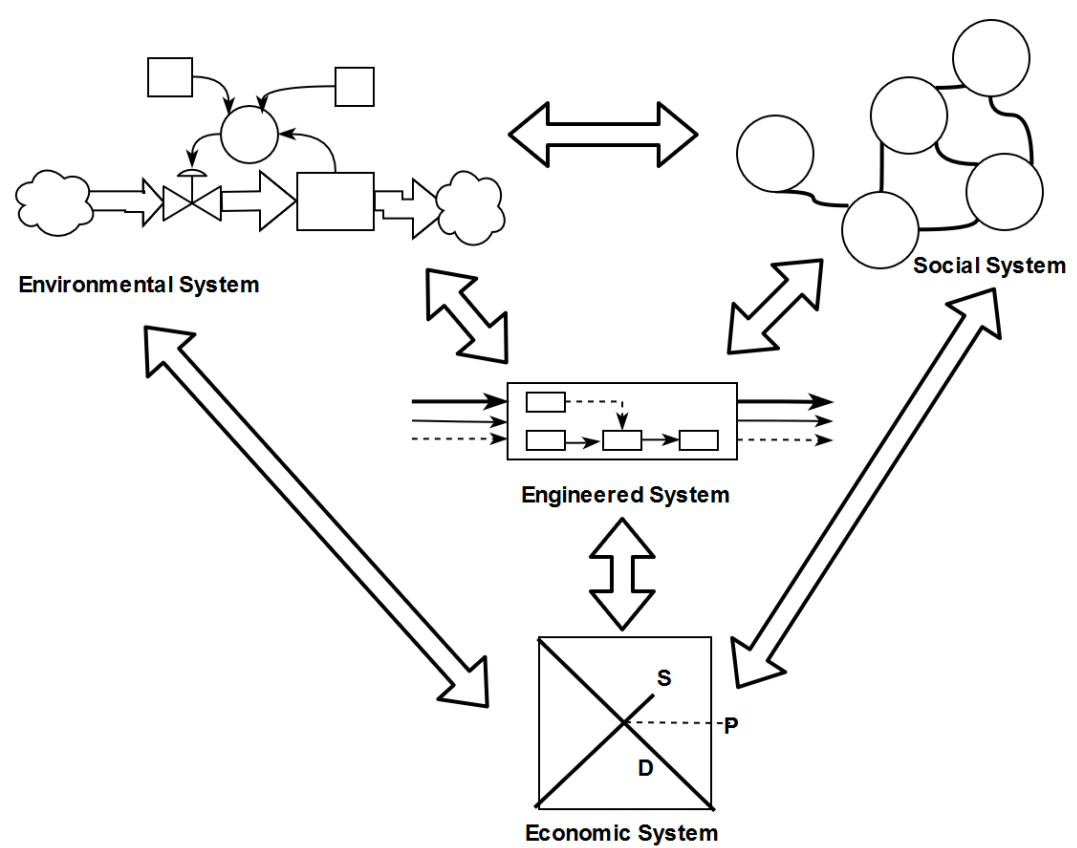

Figure 2. Three important modelling aspects of the product environment used in sustainable design: the economic, social, and environmental systems.

effectively (illustrated in Figure 3) and preventing manipulation of the decision-making process by bad actors. Generally, approaches exist to approach these issues in the decision-based design and systems engineering literature by coordinating incentives and increasing verification in the design process.

Table 5. Examining ethical issues with implementing a value-driven design approach in practice.

\begin{tabular}{|l|l|l|}
\hline Issue & Basis in Literature & Potential Solution \\
\hline $\begin{array}{l}\text { Design } \\
\text { Coordination }\end{array}$ & $\begin{array}{l}\text { Decomposing design to individual } \\
\text { designers can cause sub-optimization } \\
\text { behaviors in value-driven frameworks } \\
\text { even when incentives are aligned (Kan- } \\
\text { nan, 2015) (Hulse et al., 2018), as } \\
\text { illustrated in Figure 3. }\end{array}$ & $\begin{array}{l}\text { Enable coordination, either } \\
\text { between designers or using } \\
\text { Multidisciplinary Design Opti- } \\
\text { mization in a computational } \\
\text { environment (Kannan, 2015). }\end{array}$ \\
\hline Manipulation & $\begin{array}{l}\text { A lack of verifyability in decision- } \\
\text { making can lead to moral hazards (Hölm- } \\
\text { strom, 1979) which has ethical impli- } \\
\text { cations in that the modeller can "push" } \\
\text { predetermined decisions into the model } \\
\text { (Baker, 2017). }\end{array}$ & $\begin{array}{l}\text { Develop and adapt practices } \\
\text { from Systems Engineering } \\
\text { (e.g. (Ramesh, 1998)) to } \\
\text { make decisions tractable, } \\
\text { traceable from attributes, } \\
\text { and having a clear justifica- } \\
\text { tion that acknowledges any } \\
\text { subjectivity. }\end{array}$ \\
\hline
\end{tabular}

\section{CONCLUSIONS AND IMPLICATIONS FOR FURTHER RESEARCH}

This paper presents ethical problems within decision-based design that must be addressed in order for the set of approaches to be considered normative. While many problems were discussed, it should be noted that these problems do not necessarily prohibit the ethical and prudent use of such frameworks as they are implemented today. Indeed, considering and addressing each problem presented here would not be practical for designers, who must ultimately be able to make decisions with clarity, and are not served by engaging in paralyzing analysis which ultimately will lead to no "right answers." Instead, it points to ethical cases that must be made to support and constrain decision-based design, as well as extensions and elaborations of these frameworks which should be developed in support of using comprehensive value analysis for ethical engineering decision-making. 


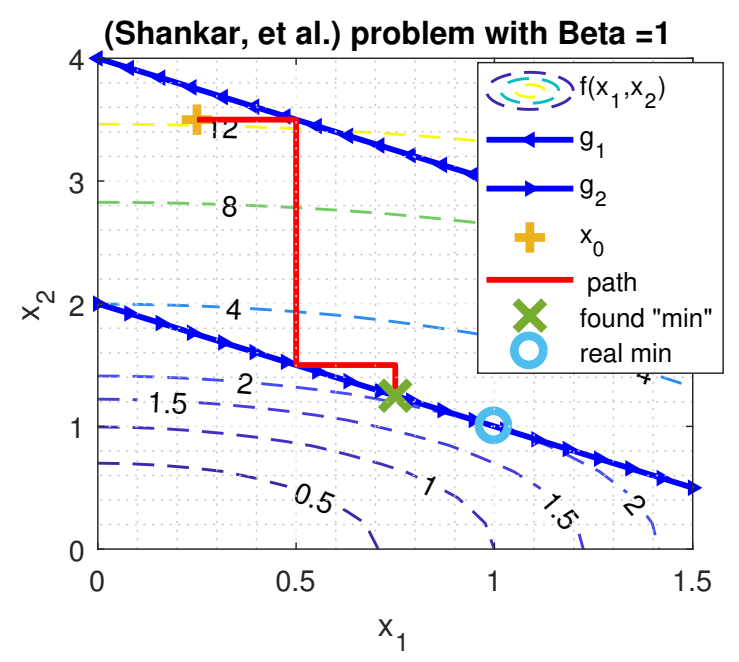

Figure 3. Optimization of a simple design problem presented by 3 with two constraints, in which the optimization of each variable has been distributed between two agents.

Optimization converges to a Nash Equilibrium rather than the true minimum, since each agent cannot lower the objective function value through their individual actions.

Finally, it should be noted that, because of the nature of this review as a productive critique meant to spur the development of future approaches, there still remain ethical cases for using Decision-Based Design frameworks not mentioned here that could justify their use both in specific cases and generally. For example, while it was noted in Section 2.1 that some regulations may be unethical to violate, it should be noted that in many cases the regulations themselves are often decided based on cost-benefit analysis (Sunstein, 2012). In this case, there may be a legitimate argument that the designer has as much right to determine the best design based on their own cost-benefit analysis, as long as it is performed prudently. Furthermore, there is a case that any attempt to deviate from immediate profit-maximization is effort that is "stolen" from the customers, stakeholders, or workers (Friedman, 2008). However, these ethical cases rely on assumptions (many of which are identified here) that need to be stated explicitly and explored further in the context of the design environment to be taken as true.

\section{REFERENCES}

Alcott, B., 2005. Jevons’ paradox. Ecological Economics, Vol. 54 No. 1, pp. 9-21.

Amy, D.J., 1984. "Why policy analysis and ethics are incompatible". Journal of Policy Analysis and Management, Vol. 3 No. 4, pp. 573-591.

Anton, J.J. and Yao, D.A., 1995. "Standard-setting consortia, antitrust, and high-technology industries". Antitrust LJ, Vol. 64, p. 247.

Awad, E., Dsouza, S., Kim, R., Schulz, J., Henrich, J., Shariff, A., Bonnefon, J.F. and Rahwan, I., 2018. “The Moral Machine experiment". Nature, Vol. 563 No. 7729, p. 59.

Baker, K.T., 2017. Simulation and "Seduction" at the Policy Interface. IEEE Annals of the History of Computing, Vol. 39 No. 3, pp.6-7.

Balinski, M. and Laraki, R., 2011. Majority judgment: measuring, ranking, and electing. MIT press.

Bhatia, G.V., Kannan, H. and Bloebaum, C.L., 2016. "A Game Theory approach to Bargaining over Attributes of Complex Systems in the context of Value-Driven Design”. In 54th AIAA Aerospace Sciences Meeting (p. 0972).

Bradley, R., Jawahir, I.S., Badurdeen, F. and Rouch, K., 2018. "A total life cycle cost model (TLCCM) for the circular economy and its application to post-recovery resource allocation”. Resources, Conservation and Recycling, Vol. 135, pp. 141-149.

Bresnahan, T.F., 1999. New modes of competition. In Competition, innovation and the Microsoft monopoly: Antitrust in the digital marketplace (pp. 155-208). Springer, Dordrecht.

Collopy, P.D. and Hollingsworth, P.M., 2011. "Value-driven design". Journal of aircraft, Vol. 48 No. 3, pp. 749-759.

Collopy, P.D. and Poleacovschi, C., 2012. "Validating Value-Driven Design". In Air Transport and Operations: Proceedings of the Third International Air Transport and Operations Symposium (Vol. 2012, p. 3). 
Dawar, N. and Parker, P., 1994. "Marketing universals: Consumers' use of brand name, price, physical appearance, and retailer reputation as signals of product quality". The Journal of Marketing, pp. 81-95.

Doyle, P., 1989. Building successful brands: the strategic options. Journal of marketing management, Vol. 5 No. 1, pp. 77-95.

Feinberg, R.M., 1975. "Profit Maximization vs. Utility Maximization”. Southern Economic Journal (pre-1986), Vol. 42 No. 1, p. 130.

Friedman, M., 1953. Essays in positive economics. University of Chicago press.

Friedman, M., 2008. "The social responsibility of business is to increase its profits". In Corporate ethics and corporate governance (pp. 173-178). Springer, Berlin, Heidelberg. Previously in The New York Times Magazine, September 13, 1970

Furubotn, E.G., 1985. "Codetermination, productivity gains, and the economics of the firm”. Oxford Economic Papers, Vol. 37 No. 1, pp. 22-39.

Gilbert, R.J. and Newbery, D.M., 1982. "Preemptive patenting and the persistence of monopoly". The American Economic Review, pp. 514-526.

Goebel, K., Smith, B. and Bajwa, A., 2019. "Ethics in Prognostics and Health Management”. International Journal of Prognostics and Health Management

Gruber, J. and Köszegi, B., 2001. "Is addiction "rational"? Theory and evidence”. The Quarterly Journal of Economics, Vol. 116 No. 4, pp. 1261-1303.

Hazelrigg, G.A., 1996. "The implications of Arrow's impossibility theorem on approaches to optimal engineering design”. Journal of Mechanical Design, Vol. 118 No. 2, pp. 161-164.

Hazelrigg, G.A., 1998. "A framework for decision-based engineering design”. Journal of Mechanical Design, Vol. 120 No. 4, pp. 653-658.

Hillinger, C., 2005. "The case for utilitarian voting”. Homo Oeconomicus, Vol. 22 No. 3, 2005. Available at SSRN: https://ssrn.com/abstract $=878008$

Hölmstrom, B., 1979. "Moral hazard and observability". The Bell journal of economics, pp.74-91.

Howarth, G. and Hadfield, M., 2006. “A sustainable product design model”. Materials and design, Vol. 27 No. 10, pp.1128-1133.

Hulse, D., Tumer, K., Hoyle, C. and Tumer, I., 2018. "Modeling multidisciplinary design with multiagent learning". AI EDAM, pp. 1-15.

James, E., 1983. "How nonprofits grow: A model”. Journal of Policy Analysis and Management, Vol. 2 No. 3 , pp. 350-365.

Kannan, H., 2015. An MDO augmented value-based systems engineering approach to holistic design decision-making: a satellite system case study. Ph.D. Dissertation.

Killmister, S., 2008. "Remote weaponry: The ethical implications". Journal of Applied Philosophy, Vol. 25 No. 2, pp.121-133.

Klotz, L., Weber, E., Johnson, E., Shealy, T., Hernandez, M. and Gordon, B., 2018. "Beyond rationality in engineering design for sustainability". Nature Sustainability, Vol. 1 No. 5, p. 225.

Kobayashi, H., 2005. "Strategic evolution of eco-products: a product life cycle planning methodology". Research in Engineering Design, Vol. 16 No. 1-2, pp. 1-16.

Le Menestrel, M., 2005. “A comment on rationality, ethical values and emotion in MCDA”. Journal of Multi-Criteria Decision Analysis, Vol. 13 No. 4, pp. 179-182.

Lee, B.D. and Paredis, C.J., 2014. "A conceptual framework for value-driven design and systems engineering”. Procedia CIRP, Vol. 21, pp. 10-17.

Leitzel, J., 1992. “Competition in procurement”. Policy Sciences, Vol. 25 No. 1, pp. 43-56.

Lewis, K., Chen, W. and Schmidt, L., 2006. Decision making in engineering design.

Meadows, D.H., Meadows, D.L., Randers, J. and Behrens III, W.W. The Limits to Growth (1972). New York: Universe Books.

Meadows, D.H. Sustainable Systems 1999. [online] Available at: https://www.youtube.com/watch?v=HMmChiLZZHg [Accessed 28 Nov. 2018].

Mistree, F., 1990. "Decision-based Design: A Contemporary Paradigm for Ship Design". Transactions, Society of Naval Architects and Marine Engineers, pp. 565-597.

Nelissen, R.M. and Meijers, M.H., 2011. "Social benefits of luxury brands as costly signals of wealth and status". Evolution and Human Behavior, Vol. 32 No. 5, pp. 343-355.

Newman, G., 2004. "Car safety and car security: an historical comparison”. Understanding and Preventing Car Theft. Crime Prevention Studies, Vol. 17, pp. 217-248.

Noor, J., 2011. “Temptation and revealed preference”. Econometrica, Vol. 79 No. 2, pp. 601-644.

NSPE Executive Committee, 2018. NSPE code of ethics for engineers. National Society of Professional Engineers. 
Olewnik, A. and Lewis, K., 2008. "Limitations of the House of Quality to provide quantitative design information". International Journal of Quality and Reliability Management, Vol. 25 No. 2, pp. 125-146.

Pahl, G. and Beitz, W., 2007. Engineering design: a systematic approach. Springer Science and Business Media.

Ramesh, B., 1998. "Factors influencing requirements traceability practice". Communications of the ACM, Vol. 41 No. 12, pp. 37-44.

Rawls, J., 1971. A theory of justice. Harvard university press.

Rosen, M.A. and Kishawy, H.A., 2012. "Sustainable manufacturing and design: Concepts, practices and needs". Sustainability, Vol. 4 No. 2, pp. 154-174.

Schwartz, M., 2010, April. Defense acquisitions: How DoD acquires weapon systems and recent efforts to reform the process. Library of Congress Congressional Research Service, Washington, D.C.

Shankar, J., Haftka, R.T. and Watson, L.T., 1993. "Computational study of a nonhierarchical decomposition algorithm". Computational Optimization and Applications, Vol. 2 No. 3, pp. 273-293.

Sheth, J.N. and Sisodia, R.S., 2002. "Marketing productivity: issues and analysis". Journal of Business research, Vol. 55 No. 5, pp. 349-362.

Shirky, C., 2011. "The political power of social media: Technology, the public sphere, and political change". Foreign affairs, pp. $28-41$.

Simon, H.A., 1959. "Theories of decision-making in economics and behavioral science". The American economic review, Vol. 49 No. 3, pp. 253-283.

Soban, D.S., Price, M.A. and Hollingsworth, P., 2012. "Defining a research agenda in Value Driven Design: Questions that need to be asked". Journal of Aerospace Operations, Vol. 1 No. 4, pp. 329-342.

Sunstein, C.R., 2014. "The real world of cost-benefit analysis: thirty-six questions (and almost as many answers)". Columbia Law Review, pp. 167-211.

Taylor, T., Greenlaw, S.A., Dodge, E.R., Gamez, C., Jauregui, A., Keenan, D., MacDonald, D., Moledina, A., Richardson, C., Shapiro, D. and Sonenshine, R., 2014. Principles of microeconomics. OpenStax College, Rice University.

Telenko, C., 2012. Probabilistic graphical modeling as a use stage inventory method for environmentally conscious design.

Thaler, R., 1980. Toward a positive theory of consumer choice". Journal of Economic Behavior and Organization, Vol. 1 No. 1, pp. 39-60.

Thaler, R., and Sunstein, C., 2008. Nudge: Improving Decisions about Health, Wealth, and Happiness New Haven : Yale University Press

Thurston, D.L., 2001. "Real and misconceived limitations to decision based design with utility analysis". Journal of Mechanical Design, Vol. 123 No. 2, pp. 176-182.

Toh, C.A., Patel, A.H., Strohmetz, A.A. and Miller, S.R., 2015, August. My idea is best! ownership bias and its influence on engineering concept selection. In ASME 2015 International Design Engineering Technical Conferences and Computers and Information in Engineering Conference (pp. V007T06A005V007T06A005). American Society of Mechanical Engineers.

Tversky, A. and Kahneman, D., 1981. "The framing of decisions and the psychology of choice". Science, Vol. 211 No. 4481, pp. 453-458.

Wassenaar, H.J. and Chen, W., 2003. "An approach to decision-based design with discrete choice analysis for demand modeling”. Journal of Mechanical Design, Vol. 125 No. 3, pp. 490-497.

Walsh, H., Dong, A., and Tumer, I., 2019. Archetypes of Unintended Consequence in Engineering. ASME International Design Engineering Technical Conference. Submitted.

Watz, M. and Hallstedt, S.I., 2018. Addressing Sustainability in Product Requirements from a Systems Perspective. DS 91: Proceedings of NordDesign 2018, Linköping, Sweden, 14th-17th August 2018.

Wenstøp, F., 2005. "Mindsets, rationality and emotion in multi-criteria decision analysis". Journal of Multi-Criteria Decision Analysis, Vol. 13 No. 4, pp. 161-172.

Wood, W.H., 2004. "Decision-based design: a vehicle for curriculum integration". International Journal of Engineering Education, Vol. 20 No. 3, pp. 433-439.

Zhuang, J., Hu, M. and Mousapour, F., 2017. "Value-Driven Design Process: A Systematic Decision-Making Framework Considering Different Attribute Preferences From Multiple Stakeholders". Journal of Solar Energy Engineering, Vol. 139 No. 2, p. 021001.

\section{ACKNOWLEDGMENTS}

This research is in part supported by the NASA Ames Research Center (award number NASA NS295A) as an I/UCRC Center for e-design project (award NSF IIP-1362167). Any opinions or findings of this work are the responsibility of the authors and do not necessarily reflect the views of the sponsors or collaborators. We would like to thank Dr. Kai Goebel for feedback and review of this paper. 